\title{
Characterization of IgM in Norwegian cleaner fish (lumpfish and wrasses)
}

\begin{abstract}
The present study comprises lumpfish (Cyclopterus lumpus) and five species of wrasses: Ballan wrasse (Labrus bergylta), Rock cook (Centrolabrus exoletus), Cuckoo wrasse (Labrus mixtus), Corkwing wrasse (Symphodus melops), and Goldsinny wrasse (Ctenolabrus rupestris). The use of cleaner fish in Norway has to a large extent been based on wild catch, but breeding of lumpfish and Ballan wrasse is increasing now. Due to disease problems, vaccine development, tools to study immune responses, and a better understanding of the immune system in these species is demanded. Here we present a comparison of the $\operatorname{IgM}$ sequences, phylogenetic relationship to other teleosts and characteristic features of $\operatorname{IgM}$ in the Norwegian cleaner fish. The lumpfish IgM heavy chain sequence was assembled from high throughput cDNA sequencing whereas the wrasse sequences were determined by molecular cloning. IgM were purified from lumpfish and Ballan wrasse sera by gel filtration followed by anion exchange chromatography, and polyclonal sera were raised against these. Crossreactivity of the sera was tested for the species mentioned, and against Atlantic salmon and cod. Protein A and protein G binding characteristics were analyzed by a Dynabeads approach, and the $\operatorname{IgM}$ concentration in sera was measured by different methods.
\end{abstract}

\section{Keywords:}

Immunoglobulin, serum concentration, phylogeny, teleost, wrasse, lumpfish, affinity chromatography, Protein A 